\title{
A CAREER AND LEARNING TRANSITIONAL MODEL FOR THOSE EXPERIENCING LABOUR MARKET DISADVANTAGE
}

\author{
ROSLYN CAMERON \\ Southern Cross University, Australia
}

\begin{abstract}
This article comes from research that investigated the learning and career transitions of those disadvantaged in the labour market. It resulted in the development of a four component model to enable disadvantaged groups navigate learning and career transitions. The four components of the model include: the self-concept; learning and recognition; career and life planning; and new literacies. The focus will be on the career and life planning component. The research utilised a sequential mixed model design which consisted of two phases. Phase one of the research involved a Learning Survey of approximately 250 labour market program participants in which quantitative data analysis techniques were used. Phase two involved the development of the model and its testing in the field. A formative evaluation of the model in the field was undertaken and utilised a combination of both qualitative and quantitative data collection and analysis. The field test was undertaken with a labour market program for women over 45 years of age wishing to re-enter the workforce. The research has resulted in the development of the model that offers career development researchers and practitioners an alternate holistic, group and community based approach to career development for disadvantaged groups.
\end{abstract}

\section{Contribution of the career development literature}

This paper will discuss the relevant research and literature that has informed the development of the career and life planning component of the model. This includes the contemporary career development literature that has addressed the changing notion of career, and associated competencies or career management skills, lifelong career development and career 
development practice and approaches that meet the needs of underrepresented groups such as the unemployed. A key concept in the career and life planning component of the model is the notion of 'possible selves' and how this is an appropriate tool for exploring adult learning and career development across the life course.

The notion of the career has changed dramatically due to the major changes occurring in the world of work and international and national interest in policies and initiatives around career development. The concepts of career and career development have changed over time to reflect: holistic views of paid employment as one facet of an individual's life; dynamic interaction between individuals, paid employment and life; a constantly changing world of work; and the necessity for individuals to be proactive life/career managers (McMahon, Patton, \& Tatham, 2003, p. 4).

Australia has developed a framework of lifelong career development programs that are structured around competencies and is embodied in the Australian Blueprint for Career Development (Miles Morgan, 2005). Patton (2005) referred to this as a constructivist perspective in developing career competencies. This perspective involves processing information to allow for the alignment of the self with information concerning occupations and contextual information in a meaningful way:

The individual's career story is the collection of images of the way the individual sees him or herself in the world. While the informational aspects of the self (e.g., interest, abilities) and of the world of work constitute the content of the story, it is the individual's constructions of these and the positioning of them within the story - the individual's narrative about self - which provides its uniqueness for each individual (Patton, 2005, p. 26). 
As a consequence Patton (2005) advocated for approaches that include journal writing, development of career action and career renewal plans, and personal portfolios.

Jarvis (2003) referred to career management skills, which provide people with the legitimate confidence in their ability to construct healthy, self reliant lives and the abilities to cope with constant and rapid change. Jarvis stated that workers in the knowledge age need:

- focus, on who they are and what they have to offer, and what is important to them;

- direction, knowing options, what appeals to them, and how to qualify for suitable learning and work opportunities;

- $\quad$ adaptability, the skill of making the best of change; and

- healthy self-esteem and self-knowledge to counter uncertainty and doubt (Jarvis, 2003, p.2).

Beddie, Lorey and Pamphilon's (2005) research study investigated learning and career development services for adults, in particular, those in some way disengaged from the labour market and educational systems. The study focused on women seeking to re-enter the workforce, older job seekers and mature-aged workers only marginally attached to the workforce. The authors concluded that for these groups:

The overwhelming majority of respondents agreed that such a community-based service, with a strong networking role, could help in meeting the career planning and learning needs of the target groups, most of whom are not career-literate and who have encountered other barriers to finding suitable occupations. Providing them with help to develop fulfilling pathways, especially if the service is provided before too long a period of disengagement, can bring multiple benefits to the 
individual, their family and their community (Beddie, Lorey, \&

Pamphilon, 2005, p. 8).

McTurk (2003) developed a model of career counselling practice for use with unemployed clients. She found that these clients face multiple barriers to employment and re-employment and that the first focus of career counselling should be to assist individuals socially, psychologically and educationally (McTurk, 2003, p. 10). Fitzgerald and Betz (1994) asserted that the major career development theories lack utility for large segments of the population in three areas. Firstly, in terms of the relevancy of the concept of career development itself. Secondly, due to a lack of attention to large groups and thirdly, the theoretical stances which fail to take into account structural and cultural factors (Fitzgerald \& Betz 2003, p. 103). The psychology-of-working framework perspective offers an alternative to traditional career development theories by providing a more inclusive and just approach to career counselling. This perspective or framework has been 'developed in response to a clear need within the field of career counselling to address the lives of those who traditionally have been ignored of forgotten because of social class, experiences of racism and other forms of social oppression.' (Blustein et al., 2008, p. 4). The four overarching objectives of this approach include: empowerment; fostering critical consciousness; skill building for the changing workforce; scaffolding toward volition (Blustein et al., 2008, p. 7).

Merriam and Clark (1991, p. 211) conducted a large study on work, love and learning in adult life. The authors claim that the greatest benefit of their research is in terms of informing practitioners (educators, counsellors, social workers and other professionals involved with personal growth and development of adults) by providing insights into how to work with adults in a holistic way whether in groups or with individuals (Merriam \& Clark, 1991, p. 224). They assert that this is achieved through a better understanding of the link between learning and development. 'Significant learning from life events results in an expansion or a transformation, enlarging a person's capacity to work and to love' (Merriam \& Clark, 1991, p. 
227). Merriam and Clark's (1991) model reflects a theme of cycles of change and stability as opposed to:

...linear career models, characterised by career progression through a rigid hierarchy and external definitions of success, may not be congruent with a cyclical life-span perspective particularly for more recent entrants to career track positions such as women and minorities' (Kerka, 1992, p. 1).

\section{Possible selves}

Possible selves has been utilised as a useful framework for understanding adult learning and change, life span development, career development and academic performance in youth (Rossiter, 2003). Cross \& Markus (1991) have identified possible selves as a significant component of self knowledge. The term is used to identify the elements of the self concept that represent individual's ideas about '.. what they could become, what they would like to become and what they are afraid of becoming, and thus provide a conceptual link between cognition and motivation' (Markus \& Nurius, 1986, p. 954). Possible selves are self knowledge concerned with an individual's potential and future. Possible selves fulfil two functions. Firstly, it functions as incentives for future behaviour and secondly, it provides an evaluative and interpretive context in which to view the current self. Interestingly, because possible selves are not anchored strongly in social experience they represent aspects of self knowledge which are most responsive and vulnerable to environmental changes (Markus \& Nurius, 1986, p. 956).

Possible selves are used as psychological resources to motivate and defend when individuals are experiencing transitions and negotiating changes within adulthood. Adult development 
theories view possible selves as blueprints for personal change and growth across the life course. Cross and Markus (1991, pp. 222-223) describe possible selves as adaptable and flexible elements of the self-system. They are often privated and not shared with others and secondly, although they are influenced by others, they are essentially defined and evaluated by the individual themselves. This process of evaluation is described by the authors as follows: "Possible selves must be revised in such a way that individuals can maintain the sense of unachieved possibility that is essential for motivation, yet still manage to feel good about themselves and their lives" (Cross \& Markus, 1991, p. 234).

Ultimately, it is the individual alone who is the final arbiter of the possible self. Only the individual can determine what is possible and what is not and only the individual can make judgements about what is a challenge, what is confirmatory or diagnostic of the possibility. A possible self cannot be disproven. There are two types of possible selves: positive and negative. Which means the positive possible self can be 'exceedingly liberating' yet the negative possible self can be 'powerfully imprisoning' as it can stifle actions for development or change (Markus \& Nurius, 1986, p. 963)

Plimmer, Smith, Duggan and Englert (1999-2000) have utilised the possible selves construct to link well-being with career development. They have combined the psychology of wellbeing and adaptability with possible selves theory to provide practical steps for career counselling. Well-being includes self-acceptance, positive relations with others, autonomy, environmental mastery, purpose in life, and personal growth. At the same time adaptability as a construct, is becoming increasingly important in career development theory (Savickas, 1993). Adaptability is defined by Magnusson and Redekopp (1992) as competence, self management and salience. Competence includes a combination of generic skills (resume writing) and specific skills (job specific skills). Self management is a mixture of strategies that encourage realistic appraisals of environmental opportunities and self control strategies to 
manage emotions and attitudes (Plimmer et al., 1999-2000). The third element of adaptability is salience which is made up of two elements: structural and contextual salience. Structural salience relates to belief and value systems and interest patterns and personal characteristics which are generally consistent over time. Contextual salience relates to individuals' perceptions of their current situations (Magnusson \& Redekopp, 1992, p. 138).

Meara, Davis and Robinson (1997) researched the working lives of women from low socioeconomic backgrounds in terms of career assessment and counselling through a possible selves perspective. They found that the possible selves framework was an effective strategy for enhancing the working alliance of this client group. Their research found that the framework was particularly useful in "...framing conversations and thoughts about the future in a non threatening manner, for integrating personal and occupational identity, and for encouraging motivation, persistence, and feelings of efficacy" (Meara, Davis \& Robinson, 1997, p. 130).

Rossiter (2003) explored the use of the possible selves construct in understanding adult learning and change and how this can act as a motivating and organising factor in transformational learning. This is done by bringing into focus a transformed sense of self-inthe-world. In fact a negative or feared possible self can serve as a trigger for reflection and questioning, especially when accompanied by with a positive possible self. This involves an exploration stage where tentative visions of new courses of action and roles are contemplated. Rossiter stated: "The process of choosing to embrace a new perspective can be understood as a process of taking on a new or altered possible self" (2003, p. 388). The role of the educator, facilitator or career practitioner is especially important in this process as they can be particularly influential in encouraging new possibilities and ways of visioning the future.

Three primary themes were identified in Rossiter's (2003) research. The first was that the interaction with and the educational relationships with teachers, advisors and mentors where a 
source and a point of origin of possible selves. Secondly, that these educational relationships provided a context for elaborating on possible selves. or the how to aspect of making possible selves a reality. Lastly, possible selves provide the stepping stones and scaffolding of transformation. This involves “...the incremental expansion of the learner's sense of possibility...to grow, change, cast off constraints, and take on new challenges" (Rossiter, 2003, p. 386).

Having explored the relevant career development literature that has informed the development of the career and life planning component of the model, the research methodology and findings will be briefly discussed before providing a fuller description of the model and its potential applications.

\section{Methodology}

The research focused on the learning experiences of those disadvantaged in the labour market and was essentially a qualitative exploratory study. The research design is based on a sequential mixed model which has two phases. In Phase I of the research a quantitative Learning Survey and qualitative focus groups were conducted. The Learning Survey was administered to approximately 250 labour market program participants on various programs in south east Queensland and northern New South Wales of Australia and was followed by a seminar which presented preliminary data to representatives of the participating organisations. During this seminar focus groups were conducted. Phase I of the research resulted in the development of a model to assist those in career and learning transitions. Phase II of the research encompassed the development and formative evaluation of the model in the field and utilised a combination of both qualitative and quantitative data collection methods. This research process was non linear and emergent which enabled the most appropriate method for progressing the research to be chosen. 


\section{Outcome}

The model was developed in Phase II of the study and involved incorporating the findings from the expanded literature review undertaken in that Phase and synthesised with the literature review from Phase I. In developing the model an interdisciplinary approach has been undertaken. Some of the key discipline areas include equity and social inclusion, adult learning theory, career development theory and psychology. The developed model sits within a policy context that acknowledges the nature and frequency of major life transitions, particularly for those disadvantaged within the labour market and/or disengaged from formal learning.

Key findings from the research points to a need for approaches to learning and career transitions that focuses on current needs and circumstances, the importance of relevancy, viewing participants from a holistic viewpoint, investigating past learning and career trajectories and possible selves (Cross \& Markus, 1991, Rossiter, 2003). Issues surrounding transitions and self-concept were crucial in informing the approaches, which would best suit and serve the needs of disadvantaged and disengaged groups.

\section{Career and learning transitional model}

The model draws upon a variety of disciplines and is considered a multidisciplinary approach to adult career transitions. The approach is holistic and the model is targeted to those in transition and disengaged from formal learning and as a consequence focuses on communitybased practice. Participants are viewed from many perspectives and contexts, in which they interact and participate in life. These include as individuals, family members, members of communities and societies, and participants within economies. Individuals are encouraged to view themselves on many levels including from a personal, intrapersonal and interpersonal

level; at a cultural and community level, and within historical, social and economic contexts. 
This approach can be said to reflect the career development systems theory framework developed by Patton and McMahon (1999). This involves several interrelated systems. "The intrapersonal system of the individual, the social system, and the environmental/societal system" (Patton \& McMahon, 1999, p. 10).

The developed model has four integrated components. These four components are visually represented below in Figure 1. Adult learning theory, career development theory and branches of the psychology field have all been drawn upon in the development of the model. The model has used an interdisciplinary approach as advocated by Fenwick (2004). She argues that there is an:

... entanglement between perspectives for understanding adult learning and perspectives for engaging with theories of adult learning...we advocate the adoption of multiple perspectives, and that closure on any single perspective reduces rather than enhances the possibilities of adult learning (Fenwick, 2004, p. 6).

Similarly, Patton and McMahon (1999, p. xix) have developed a “...metatheoretical framework for the integration of career theories using systems theory". This converges career theory and represents a shift in the comprehension of theoretical relationships within theories. Future exploration of the synergies between systems theory and the developed model are planned. Further explanation on this is not possible here given the limitations of this paper. 


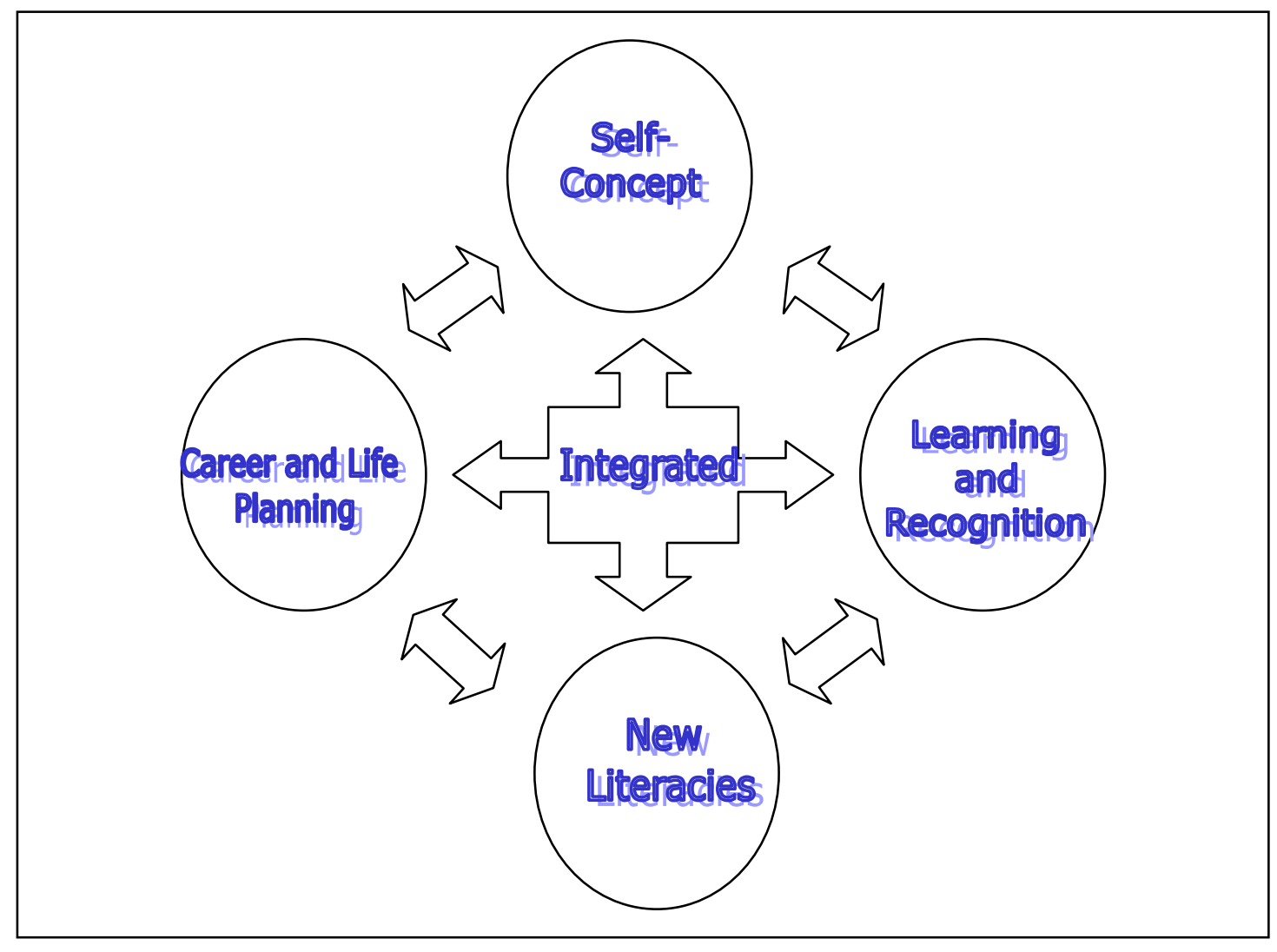

The role of the facilitator/s or career practitioner is very important in the model. This is a very valuable role, as the facilitator will need to establish explorative and formative relationships (Fowler \& Mayes, 1999) with the participants, and will need to utilise a variety of experiential learning methods to engage the participants in the four integrated components of the model. The facilitator/practitioner role allows for content negotiation with the participants, fosters critical reflection, self-direction and autonomy. The facilitator/practitioner role is also one, that assists participants to explore the social, political and historical contexts associated with their self-concept and identity; and learning careers; (Crossan et al., 2003, Gallacher, Crossan \& Field, 2002, Merrill, Field, Gallacher \& Crossan, 2001,) and the nature of their current transitional position and the risks associated with that position.

\section{Self-concept component}


The self-concept component of the new model is crucial. The issues surrounding aspects of the self-concept must be dealt with in this orientation phase before any development or progress can be made in the other areas. This component draws upon theoretical approaches that include theories of self and identity and social cognitive theory (Alexander, 2001, Branden, 1994, Dweck, 1999, Markus \& Nurius, 1986, Mruk, 1999). Key concepts addressed include self-esteem, self-confidence and self-knowledge, and development. Techniques used include an array of reflective narrative tools that include biography and storytelling as advocated by McMahon (2008). McMahon (2008) has combined the discipline fields of career development theory and identity theory to explore the adoption of narrative and storied approaches to career counselling. A variety of personal development planning strategies and techniques are also present within this component.

\section{Learning and recognition component}

The learning and recognition component looks at the different types and sites of learning (non-formal, informal \& formal). The language, systems and discourses of formal learning systems are addressed, as is a suite of 'Learn 2' skills. These 'Learn 2' skills include metacognitive skills such as 'learning to learn' and 'learning to be assessed', as well as 'learning to be recognised' skills. Central to the latter is the concept of self-recognition, which is the first phase of a three phase developmental approach to recognition (Cameron, 2004). This was further developed into three levels of recognition, and was combined with Randall's (1998) framework for restorying. It is within this component that the participants begin to develop portfolios. Participants are encouraged to explore innovative and non-paper based ways to present the knowledge and skills they have acquired through all three types and sites of learning, and the interconnectedness between them.

\section{Career and life planning component}


The third component, career and life planning, involves aspects of career guidance and development theories. Career development theories are also utilised and drawn upon within this component (Beddie, Lorey \& Pamphilon, 2005, Blustein et al., 2008, Jarvis, 2003, Patton, 2005, McMahon, 2008). Key concepts within this component are learning careers and trajectories and learner identities; the concept of possible selves (Cross \& Markus, 1991, Rossiter, 2003); and life course patterns (Merriam \& Clark, 1991). Exploration of these concepts results in comprehensive career and life plans complementary to the development of the portfolio.

\section{New literacies component}

The last component, new literacies, is based on research involving the 'new world of work' (Falk, 2002, Falk \& Guenther, 2002), the concept of the digital divide and contemporary research into conceptions of literacy for the new millennium (Lonsdale \& McCurry, 2004). Participants are exposed to macro-level concepts associated with the 'old' and 'new' economies. This includes a socio-cultural approach to literacy that values less dominant literacies, and views literacy practice as contextualised and multiple. Participants develop research and information literacy skills for the new knowledge economy. Depending on access to resources, available time and existing information literacy skills, participants are encouraged to develop e-portfolios.

\section{CONCLUSIONS AND SUMMARY}

This research has implications for career development and human resource development practice. The model offers a more inclusive, holistic, group and community based approach to career development for groups disadvantaged in the labour market and disengaged from 
formal learning systems. The career and learning transition model proposed by the research study was originally designed for a field test to meet the needs of those experiencing unemployment and transitions associated with re-entering the paid workforce after long periods of childrearing/caring, and for those experiencing unemployment and underemployment. This includes the long-term unemployed, mature-age jobseekers and those disadvantaged within the labour market. During the model's development and field test during Phase II of the research, it became clear that the model had much wider applications than its original intent. Initially, the model was designed with community-based providers of labour market programmes in mind. However, further development of the model and its multiple uses encouraged an expansion of thinking in terms of its wider applications. The fact the model is framed within the broader objectives of lifelong learning also assisted with this line of thinking. It was concluded that the model could be useful for career development interventions and strategies for the following groups and contexts:

- Existing workers in precarious employment

- Manual workers in 'old economy' employment

- Workers experiencing retrenchment and redundancy

- Equity group members and groups considered economically vulnerable

- Groups highly disadvantaged within the labour market: long-term unemployed, mature-age jobseekers, early school leavers, and those wishing to re-enter the paid workforce

- Ex offenders re-entering after a period of incarceration

- Exiting members of the defence forces

- New immigrants/migrants

- Learning communities and learning organisations

- People facing major life transitions and/or multiple transitions due to major life incidents related to health, injury, divorce and dislocation 
- Students transiting from periods of full time study in the vocational education and training and higher education

Practitioners and organisations that may be interested in the model's applications and uses could include:

- Career advisors and counsellors

- Government rehabilitation services

- Human resource and development practitioners

- Outplacement services

- Educators within schools, adult and community education, vocational education and training and higher education

- Employment services industry

- Learning organisations and learning communities

- Trade unions

- Government departments with policy briefs that include: education, training and employment, industrial relations, rehabilitation, community and economic development and social inclusion

This research focused on the experiences of those disadvantaged in the labour market. The research was undertaken utilising a sequential mixed method design. As a result of the research, a model was developed that consists of four integrated components and draws upon a variety of academic disciplines. The model was tested in the field and found to be valid. The model is targeted towards adults in transition and disengaged from formal learning and as a consequence, focuses on a group and community-based approach to career transitions. 


\section{References}

Alexander, T. (2001). Defining self-esteem. What is self-esteem and why does it matter? Self-esteem as an aid to understanding and recovery. Mental Healthcare, $4(10), 332-335$.

Beddie, F., Lorey, B., \& Pamphilon, B. (2005). Enhancing career development: The role of community-based career guidance for disengaged adults. Adelaide: National Centre for Vocational and Educational Research (NCVER).

Blustein, D., Kenna A., Gill, N. and DeVoy, J. (2008). The psychology of working: A framework for counselling practice and public policy, Proceedings of the $17^{\text {th }}$ AACC National Career Conference, $26^{\text {th }}-29^{\text {th }}$ March, Hobart.

Branden, N. (1994). The six pillars of self-esteem. New York: Bantam.

Cameron, R. (2004). RPL and mature age jobseekers. Canberra: Adult Learning Australia.

Cameron, R., \& Miller, P. (2007). A transitional model to assist those experiencing labour market disadvantage', Proceedings of the $17^{\text {th }}$ National Career Conference, Australian Association of Career Counsellors, 26 $6^{\text {th }}-29^{\text {th }}$ March, Hobart.

Crossan, B., Field, J., Gallacher, J., \& Merrill, B. (2003). Understanding participation inlearning for non-traditional adult learners: learning careers and the construction of learning identities. British Journal of Sociology of Education, 24(1), 55-67.

Cross, S., \& Markus, H. (1991). Possible selves across the lifespan. Human Development, 34, 230-255.

Dweck, C. (1999). Self-Theories: their role in motivation, personality, and development. Lillington, NC: Taylor \& Francis.

Falk, I. (2002). The new world of work: Implications for literacy and numeracy, Discussion paper prepared by Adult Literacy and Numeracy, Australian Research Consortium (Tasmania) for the ALNARC National Research Program 20012002, University of Tasmania, Launceston, (pp. 1-12).

Falk, I., \& Guenther, J. (2002). Literacy and numeracy for the new world of un/employment: Implications of a fully literate Australia. Melbourne: Language Australia.

Fenwick, T. (2004). Rethinking processes of adult learning, Retrieved July 2, 2004, from the World Wide Web: http://www.ualberta.ca/ tfenwick/ext/pubs/print/adultlearning.htm

Fitzgerald, L. \& Betz, N. (1994). Career development in cultural context: The role of gender, race, class and sexual orientation. In M. Savikas and R. Lent (eds), Convergence in Career Development Theories Implications for Science and Practice, CPP Books, Palo Alto, California.

Fowler, C., \& Mayes, J. (1999). Learning relationships from theory to design. Association for Learning Technology Journal, 7(3), 6-16. 
Gallacher, J., Crossan, B., \& Field, J. (2002). Learning careers and the social space: Exploring the fragile identities of adult returners in the new further education. International Journal of Lifelong Education, 21(6), November-December, 493509.

Jarvis P. (2003). Career Management Paradigm Shift: Prosperity for Citizens, Windfall for Governments. Partnership Development National Life/Work Centre Ottawa, Ontario, Canada. Retrieved February 14, 2003, from the World Wide Web:

http://www.lifework.ca/ACAREERMANAGEMENTPARADIGM12-02.doc

Kerka, S. (1992). 'Life cycles and career development: new models, ERIC Digest No. 119. ERIC Clearinghouse on Adult, Career, and Vocational Education, Columbus, $\mathrm{OH}$.

http://www.ericdigests.org/1992-3/life.htm [Accessed 12 Dec 2004]

Lonsdale, M.,\& McCurry, D. (2004). Literacy in the New Millennium. Adelaide: National Centre for Vocational and Educational Research (NCVER).

Magnusson, K. C.,\& Redekopp, D. E. (1992). Adaptability for transition: components and implication for intervention. Canadian Journal of Counselling, 26, 134-143.

Markus, S., \& Nurius, P. (1986). Possible selves. American Psychologist, 41, 954959.

McMahon, M. (2008). Career Counselling: Storying new identities, Proceedings of the $17^{\text {th }}$ AACC National Career Conference, $26^{\text {th }}-29^{\text {th }}$ March, Hobart.

McMahon, M., Patton, W., \& Tatham, P. (2003). Managing life, learning and work in the 21st century, Miles Morgan Australia, Subiaco, WA.

McTurk, C. (2003). A model of career counselling practice for use with unemployed clients referred from employment agencies. Australian Journal of Career Development, 12(3), Spring, 7-11.

Meara, N., Davis, K., \& Robinson, B. (1997). The working lives of women from lower socioeconomic backgrounds: assessing prospects, enabling success. Journal of Career Assessment, 5(2), Spring, 115-135.

Merriam, S., \& Clark, M. (1991). Lifelines: Patterns of Work, Love, and Learning in Adulthoo. San Francisco: Jossey-Bass.

Merrill, B., Field, J., Gallacher, J., \& Crossan, B. (2001). Understanding participation in learning for non-traditional adult learners: Learning careers and the construction of learning identities. In ESRA Research Conference, Lisbon, Portugal, 13-16 September.

Miles Morgan. (2005). Australian Blueprint for Career Development Trial Version May 2006: Subiaco, WA: Miles Morgan Australia.

Mruk, C. (1999). Self-esteem research, theory, and practice, $\left(2^{\text {nd }}\right.$ edn). New York: Springer Publishing Company. 
Patton, W. (2005). A postmodern approach to career education: What does it look like? Perspectives in Education, 23(2), 21-28.

Plimmer, G., Smith, M., Duggan, M., \& Englert, P. (1999-2000). Career adaptability, well-being, and possible selves. Career Planning and Adult Development, 15(4), 83-92.

Randall, W. (1998). Restorying a life: Adult education and transformative learning. In J. Birren, G. Kenyon, J.E. Ruth, J. Schroots and T. Svensson (Eds.), Aging and Biography. New York: Springer Publishing Company.

Rossiter, M. (2003). Possible selves and adult learning. In Experiential: Community: Workbased Researching Learning Outside the Academy Conference Proceedings, Glasgow Caledonian University, Centre for Research in Lifelong Learning, 27-29 June, Scotland, (pp. 383-389).

Savickas, M. (1993). Career counseling in the postmodern era. Journal of Cognitive Psychotherapy: An International Quarterly, 7, 205-215. 